\title{
Historein
}

Vol 4 (2003)

Public Histories

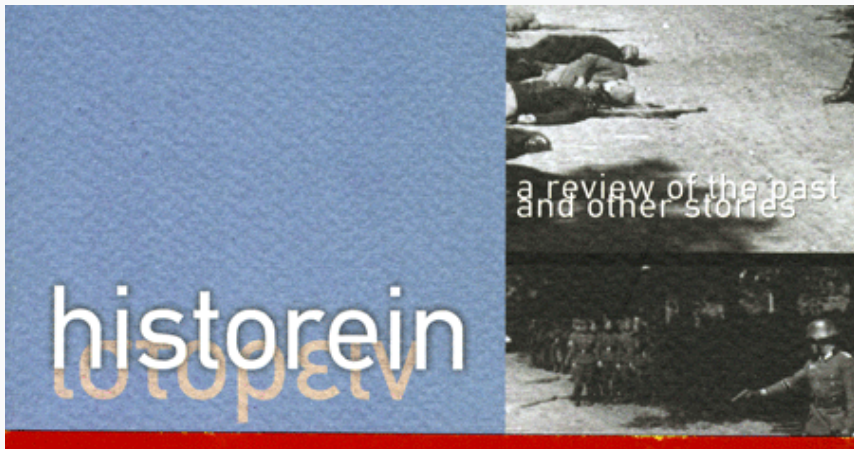

\section{Claiming History. Debating the Past in the Present} Effi Gazi

doi: $10.12681 /$ historein.81

Copyright @ 2012, Effi Gazi
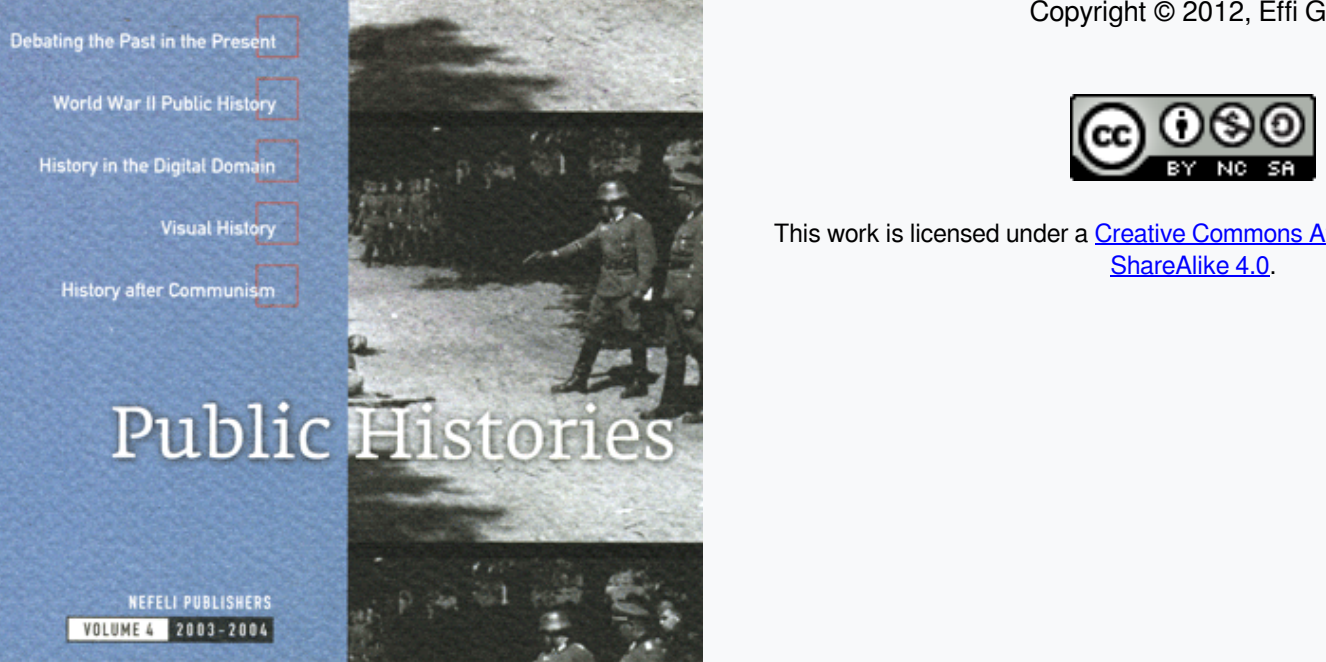

This work is licensed under a Creative Commons Attribution-NonCommercialShareAlike 4.0.

To cite this article:

Gazi, E. (2004). Claiming History. Debating the Past in the Present. Historein, 4, 5-16. https://doi.org/10.12681/historein.81 


\section{Claiming History. Debating the Past in the Present Effi Gazi}

[historein, vol. 4, p. 5-16]

The present volume is largely based on the themes, topics, and concepts explored in Historein's conference "Claiming History. Aspects of Contemporary Historical Culture," held in Athens on November 30-December 2, 2001.1 Both the conference and the volume address the issue of "the past in the present" through exploring the various facets of history in contemporary cultures. Despite their influence, contemporary representations of the past still remain a rather puzzling topic for scholarly research. Few historians are interested in them and even fewer are prepared to aknowledge them as worthy contributions to a wider historical culture. Still, the past's "second life," as Antonis Liakos defined images and representations of the past in his opening address at Historein's conference, not only play an important role in the processes of self identification societies are undergoing, but also offer an area of study that is critical for an overall assessment of history making itself. 2

The issues involved in the study of this specific topic are diverse, as was reflected in the titles of the conference's various panels, "The Memory of History," "Historical Traumas and their Return," "Public History," "When the Past is Displayed," "Images of History," and "When Literature is Historicizing." First, there is the question of "ownership" and "authority." "Who has the authority to speak about the past?" wonders Ludmilla Jordanova in a relatively recent article on public history. 3 Do professional historians devoted to scholarly research have a privilege over others? The question becomes critical in this particular historical moment when "historical illiteracy" and "cultural amnesia" seem to prevail while a powerful presence of various "pasts" dominates contemporary public debates. 4 As a result, it is necessary to explore the various claims on history, bearing in mind that history is a word of many meanings mainly revolving around the academic discipline of historical studies as well as the diverse set of political, cultural, and social practices that focus on the "past."

The twentieth century, in contrast to the nineteenth, was not particularly generous towards academic history in the sense that neither the special institutional role it had previously achieved nor its claim to scientific objectivity were enhanced. The study of history developed into an institutionalized discipline during the nineteenth century through a combination of the supremacy of national ideologies, especially in Europe, and the advantageous position the field was given in shaping national, social, and gender identities, particularly along the perspectives of middle class politics. At the end of the nineteenth century, however, the balance shifted. The uniform "paradigm" of a science of history based largely on the scientific presuppositions of German historicism was powerfully challenged both within the field of history itself as well as outside, in other social sciences (i.e.sociology). The Annales School, the British Marxist historians, German historical social science, women's and gender history, subaltern history are just a few very well known contributors to the formation of new theoretical and methodological axes for the research and writing of history. These new axes undermined the application of a single, organized, and general historical paradigm, at least comparable with what nineteenth century historiography had preached. $\underline{5}$ A vast array of theoretical perspectives, methods, and subject-matters co-exist in the study of the past today. The variety and diversity of approaches to history were reinforced by the demographic explosion of the community of historians worldwide, which completely undermined the "white, male, middle class" figure of the prominent historian and allowed for the inclusion of several "others." This demographic explosion has led to the growing of the community (as well as to the diversity of its audiences) to such an extent that, as Frank Ankersmit has put it, there are "more historians occupied with the past now than the total number of historians from Herodotus until 1960."

Reflection over the nature of the discipline of history became more pronounced during the last three decades. Interest did not focus exclusively on research agendas but also on the purposes and features of the final historiographical product. The cultural shift in the social sciences has clearly left its mark upon theoretical debates and has triggered an intense, productive, but painful process of rethinking the functions of history as well as the frameworks of historical knowledge. This process generated an identity crisis among professional historians that occurred at a time when funding for historical research was reoriented. It is generally acknowledged that, from the 1980 s onwards, research in the social sciences has been experiencing an overall economic crisis. This is also the case for history, although there are some qualitative differences. On the one hand, the academic substructures that protected history ceased to exist and, on the other, state interest in historiographic production was greatly reduced. In terms of funding, historical research itself became gradually dependent on private institutions. 
While academic history is experiencing the consequences of both a self-reflective process and limited state funding, increasing public interest in the past is generating a growing market for history products. This is a multi-faceted market involving centers of historical studies, special issues in both printed and the electronic media, museums, tourist shops, cd-roms, and hightech, expensive film productions. All this is in addition to the explosion of historical literature, with an emphasis on the historical novel, which is often combined with personal memoirs, life stories, and testimonies.

The development of this huge web of activities surrounding history is becoming a worldwide phenomenon that has been defined as the "memory industry." The term "industry," however, is somewhat misleading. It successfully illustrates the business-like nature of the phenomenon as well as the mass production and consumption of history products. However, it neglects the communicative, often interactive, dimension and indirectly downgrades the fact that this activity encompasses a wider historical culture in which subjective and collective perceptions of the past coexist, often expressed in particularly dynamic and creative ways.

History is everywhere today. Of course, one might say that this has always been the case since different images of the past have always been produced, framed, and circulated in various epochs depending on their wider historical culture. In her contribution, for example, Ioanna Petropoulou discusses the changing frames of historiography developed within the Orthodox communities of the Ottoman Empire during the nineteenth century and the ways they complemented their self-image. There is, however, a qualitative shift today in the sense that increasing interest in the past, defined either as popular or commercial, constantly addresses wider audiences and persistenly develops in new directions.

One of the many reasons for the popularity of history today is attributed to the development of new technologies and mass communication media. According to this line of analysis, mass media transform representation as such and reconceptualize it particularly by incorporating developments related to the digital and multimedia domains. In his contribution, Gregory Paschalidis explores the multiplication of photographic histories today and the rise of new kinds of visual histories. The second media age leads to new codes of narrating and perceiving experience, including vision itself in an age of visual culture. This re-articulation of experience within the socalled visual or iconic turn necessarily includes the past because all mnemonic material is constructed around new standards and new modes of communication. 7 Communication itself becomes of primary importance since new techological developments primarily relate to the circulation of information. Living in an age of information surplus inevitably contributes to theorizing about information and communication even within the domain of historical research and interpretation.8 Mark Poster's contribution in the present volume raises the complex epistemological issues involved in the interplay of "analogue" and "digital" truth and discusses how they affect the historical discipline particularly with reference to the digitization of data.

The major role of mass media in images and interpretations of the past cannot be disputed, and the focus on communication and media studies in order to promote research in mnemonic communities may be particularly useful. $\underline{9}$ Making social and cultural phenomena exclusively subservient to changes generated by the media, however, both makes these phenomena independent of the social contexts at large and ignores their fundamental relation to the wider domain of cultural production. Undoubtely, the media are important players in the field. They participate actively, playing a crucial role in reproducing historical information of all kinds and codifying past narratives. They do not, however, act alone. Images of history in the public domain must be interpreted on the basis of interaction between the mass media and political formations as well as contemporary socio-cultural preoccupations. Our primary interest is in the dynamic of the joint production of historical meaning.

The flight to the past has grown largely out of the prolonged nostalgia already kindled by modernity in the nineteenth century. Nostalgia, affection for anything old, the search for a lost utopian paradise, is a cultural and intellectual phenomenon that has left its mark upon modernity. Modernity's ambivalence towards itself and the changes that have emerged by disrupting its links with traditional societies is evident in continuous efforts to manage a huge memory bank while at the same time providing a sense of relief for the anxiety brought on by an industrialized and anonymous world. There probably has not been another period as nostalgic as modernity. Its adherence to nationalism, one of its central ideologies, is indicative of its retrograde nature and its dependence on remote pasts. The contradiction is perceptively pointed out by Jacques Le Goff, when he states that, "if it (the modern) attacks the ancient, it turns to take refuge in history. Modernity and a taste for earlier styles go together." 10 During 
the twentieth century, the traumatic experiences of totalitarianism, warfare, genocide, violence, colonialism, and ecological disasters bolstered feelings of nostalgia, paving the way for a negative or at least ambivalent attitude towards modern ways. In his contribution, Michael Löwy discusses Walter Benjamin's conception of (particularly modern) history, defining it as a rather pessimist philosophy based on German romanticism, Jewish messianism, and Marxism in which revolution emerges as the necessary rupture of a historical process leading to catastrophe.

The formation and development of new collectivities attempting to explore and consolidate their particular identities after World War II bolstered this tendency to seek refuge in the past. "Never before have so many linked themselves to so many and different pasts," claims David Lowenthal.11 "Identity wars" and "culture wars" play a major role in contemporary public debates. "Identity politics" tend to provoke the reaction of many commentators, intellectuals, and activists. They are often interpreted either as naive responses to complex political realities or as inherent to the cultural logic of late modernity or postmodernity. 12 This approach overlooks the fact that, explicitly or implicitly, these particular processes are set in a deeply political field, that of the formation of subjectivities and collectivities within social contexts that generate a conceptualization of politics along cultural definitions. They should be judged accordingly.

The formation of new subjectivities and collectivities is the result of a complex set of new or relatively new economic and socio-cultural phenomena:

a. The new immigration waves that appeared after both World War II and from the 1980 s onwards following the previous one of the end of the nineteenth and the beginning of the twentieth century. The new waves involve populations from both postcolonial and postcommunist environments whose experiences and identities are greatly varied. They generate great fluidity in the fields of legal and illegal employment, education, and entertainment, intensifying the multi-racial, multi-national, and multi-cultural nature of countries such as the United States, Canada, Australia, and many European countries. b. The transformation of national states, the rise of postcolonial regimes, the development of supra-national institutions such as the European Union, and the fall of communist regimes. These evolutions threw established structures into disarray and resulted in new perceptions of collective identities and new patterns for their representation. Long lived collective units have lost some of their power or, at least, have become increasingly forced to co-exist with alternative structures. Such structures have been established by private, individual, and transnational organizations much more frequently in recent years than was the case even as recently as the 1980s. In this context, Ulf Brunnbauer's article can be studied vis-à-vis Ivan Elenkov's and Daniela Koleva's contribution. While the former addresses the ideological and political framework of interpretations in nationalist historiography in the Republic of Macedonia (FYROM), the latter focusses on the new debates launched after the fall of communism in Bulgaria (i.e. the one on facism) in an attempt to re-conceptualize the past. Hara Kouki, on the other hand, discusses the restructuring of history (particularly of the Stalinist period) under perestroika in the late days of the Soviet Union, addressing the official interest in new models of socialism and transformations of the Communist Party as well as the public interest generated by a conceptualization of remembrance as a form of resistance.

c. The intensive process of globalization. It has strengthened our ability to communicate and convene while also making more and more people aware of class, gender and race differences, political disparities, economic inequalities, and the internal hierarchies within the "new world order."

New collectivities in the global society consist of classes, minorities, electronic communities, and ethnic, cultural, racial associations whose territorial location is secondary to their consolidation and whose channels of communication might extend worldwide.

Under these conditions, collective and subjective memories have once again established their role as defining factors of identity, turning history into a field of competition as it draws the interest of continuously growing audiences and incorporates painful and often controversial issues. The flavour of the past infiltrates almost every fold of collective activity. In his lengthy and rich contribution, Hagen Fleischer explores extensively and intensely the resurgence of World War II images in a great variety of contexts and countries after the collapse of communism, showing that the processes of Vergangenheitsbewältigung have generated entire "commemorative marathons," conflicts, and re-negotiations in most of Eastern and Central Europe.

Professional historians often have persistent reservations about public images of the past, interpreting this "history mania" as the counterpoint of sound historical knowledge and thought. 
At best, these renditions are considered to be part of a commercial production line that includes historical novels and Hollywood blockbusters, but also museums and galleries of dubious worth containing historical inaccuracies and cheap tourist souvenirs. At worst, they turn history into an ideological weapon used by private, national, or trans-national agencies promoting their own, individual agendas. Many historians have a very superficial interest in the ways in which history functions in the wider public domain. They are trained to work alone along traditional lines of professional discourse, their professional ethos is individualistic, they have great difficulty in transplanting research for various publics, and they often share a distaste for popularization. 13 Quite a few deal with this glut of "misrepresented" history on the altar of commercialization only through ridicule and distance.

Such reactions are part of a wider mistrust of the products of modern and, mainly, postmodern popular and mass culture. One cannot but take into serious consideration some of the most important theoretical and analytical insights in this direction. Fredric Jameson, for instance, has identified postmodern culture as the de-realization of experience, identity, and history. In an age of the primacy of the visual and the virtual that generates "simulacra," that is "identical copies for which no original has ever existed," a postmodernist nostalgia arises primarily defined by the disappearance of the historical referent. The past is turned into "pop history," Jameson argues, and "we are condemned to seek History by way of our own pop images and simulacra of that history, which itself remains out of reach."14 Many commentators, inside and outside the historical profession, share similar reservations. According to David Lowenthal, for example, contemporary leanings in history and "heritage" constitute both a creative art and an act of faith which mainly looks towards the domestication of the past. 15 It is a web of activities that addresses sentiment more than critical thought. It translates the past in terms of the present, making it familiar and approachable in order to serve the needs of the present.

Coming from different starting points, critical lines of thought converge in some shared conclusions about the nature of history in contemporary public domains. To begin with, they contain, to a certain extent, the underlying assumption that the construction of historical knowledge is value-free and disinterested, independent of ideological or political postures. The distinction between a scientific history exlusively promoting the truth and a non-scientific one viewing the past through distorted lenses is erroneous, and if taken to extremes, can provide a legitimizing framework for many versions of academic historiography that are anything but objective. Certain approaches that tend to become overcritical of public images of the past focus on crystallized positions based on historical misinterpretations and are oriented towards a distorted past for mass usage. They combine reservations about contemporary popular culture with doubt about the uses of a past not based on the solid foundations of an organized discipline.

This is where the main problem for the analysis of historical culture lies. How is it possible to comprehend that "history as an academic discipline is only one of the factors in forming memory?"16 How can the fluid and ever-changing field of compiling meanings and perceptions of the past be approached through different feelings, traumatic experiences, accusations, objections, and conflictual interpretations with formally or widely held opinions? How can the fields of individual and collective memory come together and how can disputed views about history be interpreted? How, finally, can the many layers of time on which individual and collective identities assemble be understood?

History and memory are not strictly divided into mass produced products for the many and special products for the few, but are defined by the floating meanings of the past in the present. The study of historical culture focusses on all means, ways, and media by which individuals and groups of people develop their sense of the past by emphasizing the palimpsestic nature of contemporary historical consciousness and the "dialogic layering of various voices." 17 In any case, a wide definition of history includes the communicative processes and networks through which communities of interpretation and their conceptualizations of the past emerge. These communicative processes establish the discipline of history as an active component of the wider cultural scene and turn it into one but definitely not unique of the interlocutors in the debates about the past. 18

In this vein, the primary requirement for reassessing historical culture is greater flexibility by professional historians towards the various representations of the past. This flexibility is needed so historians can free themselves from the role of controlling or even policing public images of the past and, instead, deal with the substantial issue of understanding what constitutes history as a form of cultural memory in contemporary societies and what its function is.19 Studying the communicative aspect of historical culture and its systems of representation turns our interest 
into socio-cultural phenomena of primary importance. There are many benefits from such an approach. It lifts the distinction between a past fenced inside a specific instance in time and space and its image within time and through time and space. It conceptualizes the various images and reconstructions of the past as intrinsic elements in the composition of societies. Through interplay between different periods of time, it encourages greater sensitivity towards understanding the past through the eyes of those who lived it and those who are still experiencing it in its various forms. It redefines the role of history and the role of historians within society.

Despite the plea for historians to be more flexible, one can not really argue that historians are by definition indifferent towards increasing public interest in the past. The shift of interest in historical research towards the areas of memory, subjectivity, and experience largely reflects the dynamics of a growing field of studies focussing on the parameters of social remembrance and the features of historical culture. It is not at all by chance that this interest emerged and developed in a period when the "grand narratives" with which modernity clothed history fell apart while at the same time new collectivities appeared claiming "their" past.

The "places of memory," as Pierre Nora20 accurately described them, now constitute a large segment of theoretical thinking and empirical research in the field of historical and anthropological studies, mainly focussing on the social and cultural dimensions of mnemonic processes, on the ways images of the past anchor in the worlds of individuals, and on the multiple time frameworks within which the meanings of history unfold. These interrelated approaches base their interpretative processes on certain assumptions that insist more on the social function of memory and less on its authenticity, the objective recording of the incidents it recalls. From the social frameworks of memory Maurice Halbwachs studied at the beginning of the century 21 to the anthropological approaches today, memory function is perceived as a social event and its "order of things" is defined according to the priorities of the framework within which it develops instead of according to the priorities of the past to which it refers.

Such an approach has stimulated intense debate among historians. The claim that the common professional direction of historical research has been lost forever and that one should refer to at least two co-existing "paradigms" in historical studies is based mainly on the fact that contemporary history is "divided between the logic of memory and the demands of 'scientific' knowledge." 22

In addition, the relatively new field of public history is oriented towards another procedure. It seeks to involve the historical community more substantially with the technologies and means of producing and promoting historical knowledge. The main goal here is not to be exclusively concerned with the approach and analysis of various forms of historical culture as particular subjects of research, but, instead, with directing historical knowledge towards and mainly with larger audiences within new research and working environments that include museums, television programs, and movie theaters.

Within this framework, public history acts as a bridge between academically organized historical knowledge and the people's living experience, taking advantage of new technical capabilities (digital archives, internet communication, multimedia). Its goal is to develop an interactive space between the professional historian, the object of history (such as ruins, archives, collections), and the public at large.

This interactive function is based on the fact that it recognizes the differences between organized academic knowledge about the past and public memory and attempts in several ways (exhibitions, museums, digital or on-line presentation of archives) to bridge this deep gap and promote historical sensitivity. 23 As noted by Susan Crane, cultivation of historical thought requires time and patience, but also willingness on the part of historians and anyone professionally involved with "administrating" the past to "incorporate personal memories in the production of history." 24

My approach however, distances itself from a very narrow definition of public history that is concerned primarily with managing real or invented "heritages" or focusses exclusively on the presentation of historical material to non-academic audiences. 25 It embraces a broad definition that seeks to relate critical historical knowledge to wider social concerns and needs. From this point of view, it privileges the study of historical culture over the exercise of a business-like narrowly defined public history. The "privatization" of the past that surfaces in contemporary societies definitely relates to the fascination with the concept circulating in intellectual and public debates. It implements, however, a wide range of practices evolving mainly around the 
issues of "testimony" and "commemoration." Both reveal an intense and complex negotiation with past realities that are being decontextualized and recontextualized in ways that require a critical analysis by historians and historically sensitive individuals. 26

The history of historians, that is, the academic version of history, is quite different from the history with which various social groups are concerned largely because it uses its own special codes in composition and expression. This, however, does not always assure its qualitative superiority nor is its isolation legitimized by a sterile attempt to defend itself from real or imaginary dangers embodied within the public images of the past. In any case, the distance from its social production that was promoted during its efforts to establish itself as an academic discipline threatened to transform it into becoming a signifier with no signified.27 If the goal of critical history is to democratize knowledge and widely promote critical thinking, the study of historical culture and a broad public history both contribute through two separate but converging routes. Firstly, they try to understand the economic, political, ideological, and cultural axes that determine the wider meanings of the past and the continuously developing history market. Second, they try, metaphorically speaking, to "de-professionalize history," as Raphael Samuel once put it.

In no way must this point be perceived as an attempt to destabilize the methodological and theoretical principles of scholarly research. It must be understood as a starting point for promoting the widening of historical knowledge on the basis of a developed "inter-subjectivity" between the interpretations of the past to which historical research leads and the perceptions of social subjects defined by their own historical experience. The "history at large" program introduced by the journal History Workshop in the late 1970 s is very similar to this approach.

The discipline of history may have failed to reach the basic goal it once set for itself, that is to describe "things as they exactly happened." Its long development through the nineteenth and twentieth centuries, however, clearly has provided the tools and methods that make it possible to say "how things did not happen." 28 It is an organized field of knowledge, oriented towards indepth research and the acquisition of knowledge. The procedure for acquiring knowledge, however, will be much more productive if historians, or individuals with an education in history, can study and understand "the subjectivity of individuals in their historical perception of themselves."29 Public history and the study of historical culture in contemporary societies is a huge and extremely complex domain. It needs to be recognized, and it needs to be developed with active contributions from those promoting a pluralistic, multi-vocal, but critical and democratic way of historical thinking.

1 On the conference, see Polymeris Voglis's review, Historein 3 (2001), pp. 205-207.

2 Antonis Liakos, "Opening Address" to the conference, Claiming History. Aspects of Contemporary Historical

Culture (unpublished).

3 Ludmilla Jordanova, "Public History," History Today, May 2000, p. 21.

4 For a similar set of questions, see Ann-Luise Shapiro, "Whose (Which) History is it anyway?," History and

Theory $36(4), 1997$, pp. 1-3.

5 Rolf Torstendahl, "An Assessment of 20th-Century Historiography: Professionalisation, Methodologies,

Writings," Proceedings of the 19th International Congress of Historical Sciences, Oslo 2000, pp. 101-122.

6 Frank Ankersmit, "Historiography and Postmodernism," History and Theory 28 (2), 1989, pp. 137-153 (138).

7 Gary R. Edgerton, "Introduction: Television as Historian: A Different Kind of History Altogether" in: Gary R.

Edgerton and Peter C. Rollins (eds.), Television Histories. Shaping Collective Memory in the Media Age, 
University Press of Kentucky 2001, pp. 1-16. For the impact of new media technologies on history, see also

Despoina Valatsou, "The Center for History and New Media (CHNM)," Historein 3 (2001), pp. 200-204.

8 Frank Ankersmit, op.cit., p. $140 \mathrm{ff}$.

9 For an analysis of memory studies in relation to communication and media studies, see Wulf Kansteiner,

"Finding Meaning in Memory: A Methodological Critique of Collective Memory Studies," History and Theory 41 (2002), pp. 179-197.

10 Jacques Le Goff, History and Memory, transl. Stephen Rendall and Elizabeth Claman, Columbia University Press, New York 1992, p. 50.

11 David Lowenthal, The Heritage Crusade and the Spoils of History, Cambridge University Press 1998,

p. 3. See also pp. 5-11.

12 See, for instance, Slavoj Zizek, "Multiculturalism or the Cultural Logic of Multinational Capitalism," New

Left Review 225, Sept.-Oct. 1997, pp. 28-51.

13 For a similar point, see J. M. Winter, "Public History and Historical Scholarship," History Workshop Journal

42 (1996), pp. 169-172.

14 Fredric Jameson, "Postmodernism, or the Cultural Logic of Late Capitalism," New Left Review I/146, July-

August 1984, www.newleftreview.net, 16/1/2003.

15 David Lowenthal, op. cit., p. xv, xvii, et al.

16 Georg Iggers, "The Uses and Misuses of History. The Responsibility of the Historian, Past and Present"

in: Solvi Sogner (ed.), Making Sense of Global History, Oslo 2001, p. 313.

17 Vivian Sobchack, "The Insistent Fringe: Moving Images and Historical Consciousness," History and Theory

36 (4), 1997, pp. 4-20 (7). See also, Hayden White, "Historiography and Historiophoty," American Historical

Review 93 (5), 1988, pp. 1193-1199.

18 On the communicative networks of the production of historical knowledge, see Antonis Liakos,

"Towards a Poetics of History", Historica 31 (1999), pp. 259-290 [in

Greek]. See also, Luisa Passerini, "History and Semiotics," Historein 1 (1999), pp. 13-20.

19 For the meaning of "policing" the past, see Gary Edgerton, op. cit., p. 6.

20 Pierre Nora, Les Lieux de Mémoire, Paris 1984-1992.

21 Maurice Halbwachs, Les Cadres Sociaux de la Mémoire, Paris 1925.

22 Rolf Torstendahl, op. cit., p. 119.

23 For these issues, see mainly the definitions of "public history" at www.publichistory.org as well as references

to related links in the same website. 
24 Susan Crane, "Memory, Distortion and History in the Museum," חistory and Theory 36 (1997), p. 44-63,

www.wilsonweb.com, 7/3/2001.

25 On the narrow definitions of public history, see the comments by L. Jordanova, op.cit., p. 20.

26 The insights on the "privatization" of the past and the contrast between "testimony" and "commemoration"

are developed by Frank Ankersmit in his Historical Representation, Stanford University Press 2001,

pp. 149-175.

27 On the semantics of history, see Sande Cohen, Historical Culture: On the Recoding of an Academic Discipline,

Berkeley: University of California Press 1986, p. 331 et al.

28 Georg Iggers, "The Uses and Misuses of History...," op. cit., p. 317.

29 Lutz Niethammer, Posthistoire. Has History Come to an End?, transl. Patrick Camiller, London, Verso,

1992, p. 149. 